\title{
Development of Nanocapsule Suspensions and Nanocapsule Spray-Dried Powders Containing Melatonin
}

\author{
Scheila R. Schaffazick, ${ }^{a}$ Adriana R. Pohlmann, ${ }^{a, b}$ Graziela Mezzalira $^{a}$ and Sílvia S. Guterres ${ }^{*, a}$ \\ ${ }^{a}$ Programa de Pós-Graduação em Ciências Farmacêuticas, Faculdade de Farmácia, Universidade Federal do Rio \\ Grande do Sul, Av. Ipiranga, 2752, 90610-000 Porto Alegre-RS, Brazil \\ ${ }^{b}$ Departamento de Química Orgânica, Instituto de Química, Universidade Federal do Rio Grande do Sul, CP 15003, \\ 91501-970 Porto Alegre-RS, Brazil
}

\begin{abstract}
Suspensões de nanocápsulas contendo melatonina foram preparadas pelo método de deposição interfacial e caracterizadas (tamanho, morfologia e eficiência de encapsulação). Foram avaliadas as influências do tipo de polímero, de óleo e de tensoativo sobre as características dos produtos. A eficiência de encapsulação da melatonina variou de $30 \%$ a $56 \%$ e a natureza do polímero foi o parâmetro de maior influência. De acordo com a maior eficiência de encapsulação, nanocápsulas preparadas com Eudragit $\mathrm{S}_{100^{\circledR}}$ foram selecionadas para secagem por aspersão, objetivando-se aumentar a estabilidade física das suspensões e controlar a liberação da melatonina. O pó obtido apresentou eficiência de encapsulação de $93 \%$ e não sofreu nenhuma alteração morfológica após 12 meses de armazenamento. Este sistema apresentou perfil de liberação controlado, comparativamente ao fármaco puro, o qual foi ajustado ao modelo monoexponencial. O mecanismo de liberação da melatonina foi baseado em intumescimento e dissolução do polímero.
\end{abstract}

Nanocapsule suspensions containing melatonin were prepared by interfacial deposition method and characterized (size, morphological aspect and encapsulation efficiency). The formulation parameters studied were the oil nature, the type of surfactants and the type of polymer. The melatonin-encapsulation efficiency ranged between $30 \%$ and $56 \%$ and polymer nature was the parameter that more influenced the characteristics of suspensions. According to the highest encapsulation efficiency, the nanocapsules prepared with Eudragit $\mathrm{S} 100^{\circledR}$ were selected to be spray-dried in order to improve the physical stability of suspension and to control the release of melatonin. The melatonin-loaded nanocapsule spray-dried powder presented encapsulation efficiency of the $93 \%$ and no morphological alterations were observed after 12 months of storage. This system showed a controlled release profile in comparison to the dissolution of the pure melatonin. The release profile was fitted to monoexponential model and the melatonin release mechanism was based on swelling and dissolution of the polymer.

Keywords: melatonin, nanocapsules, nanoparticles, spray-dried powders

\section{Introduction}

Melatonin, $\mathrm{N}$-acetyl-5-methoxytryptamine (Figure 1), is a hormone secreted at night-time by the pineal gland of mammals and it is involved in the regulation of the sleepwake cycle, as well as in several biological functions, such as the modulation of mood, the control of seasonal reproduction in animals, the circadian rhythm regulation, the normal patterns of sleep, ${ }^{1}$ and the neuroimmunomodulation in humans. ${ }^{2}$ The administration of the exogenous

* e-mail: nanoc@farmacia.ufrgs.br melatonin has been employed for circadian rhythm disorders as jet-lag and insomnia. ${ }^{1}$ Beyond the potent antioxidant activity, the melatonin is a free radical scavenger, ${ }^{3}$ protects against lipid peroxidation in several models ${ }^{4}$ and against oxidative stress observed in some neurodegenerative diseases such as Alzheimer. ${ }^{5}$ It also protects against ischemia/ reperfusion injury $^{6}$ and presents anti-tumor activities. ${ }^{7}$

However, melatonin has a very short half-life, low and variable bioavailability, presumably due to extensive first-pass metabolism and/or variable absorption, when administered orally. For these reasons melatonin is not a good candidate for conventional oral immediate-release 


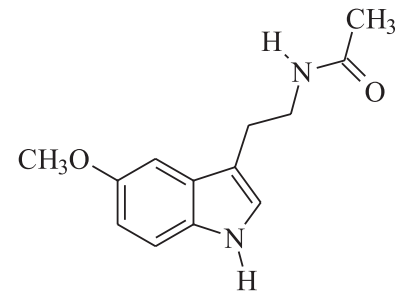

Figure 1. Melatonin structure ( $N$-acetyl-5-methoxytryptamine).

formulations. ${ }^{8,9}$ Indeed, exogenous melatonin in sustained release formulations were reported to be clinically more useful to maintain sleep and treat circadian rhythm disorders when compared to immediate release formulations. In this way, sustained release dosage forms to deliver melatonin have been investigated ${ }^{8-14}$ Lee et al. ${ }^{8}$ obtained sustained release formulations of melatonin using hydroxypropyl methylcellulose matrix tablets. According to the studies conducted by Lee and Mim, ${ }^{11}$ the sustained release formulations of melatonin using alginate beads may be an alternative for oral delivery of this drug. El-Gibaly et $a l .{ }^{9}$ have developed buoyant melatonin-loaded chitosan microcapsules presenting sustained release characteristics. They verified that these microcapsules were more effective in reducing the aflatoxin B1-induced apoptotic rate than free melatonin.

The interest in nanoparticulate systems for controlling release of drugs has been growing in pharmaceutical field for parenteral, oral or topical administration. Nanoparticles are defined as colloidal polymeric particles containing a drug, including nanocapsules and nanospheres. Nanocapsules are carriers composed of an oil core surrounded by a polymeric wall, whereas nanospheres consists of a polymeric matrix. ${ }^{15-17}$ Both colloids are stabilized by surfactants at the particle/ water interface. These systems can be prepared by methods based on the polymerization of dispersed monomers or the dispersion of a preformed polymer. ${ }^{18}$

For i.v. route, nanoparticle suspensions have been developed for drug targeting delivery, improving the therapeutic index, ${ }^{15,17,19}$ whereas for oral administration, polymeric nanoparticles have been studied for protecting the mucosa from the toxicity of drugs ${ }^{20}$ for sustaining the release of drugs ${ }^{21}$ and for improving of the bioavailability of drugs. ${ }^{22}$ However, these aqueous suspensions present disadvantages because during the storage physico-chemical instability due to the agglomeration and the sedimentation of particles ${ }^{23,24}$ and microbiological contamination can occur. In the literature, approaches employing freezedrying ${ }^{23,25,26}$ and spray-drying techniques ${ }^{27,28}$ have been reported in order to improve the stability of nanoparticles by means of the convertion of the suspension into powders. In previous studies we obtained oral solid forms containing non-steroidal anti-inflammatory drug-loaded nanoparticles, using spray-drying technique and colloidal silicon dioxide $\left(\right.$ Aerosil $200^{\circledast}$ ) as drying adjuvant. ${ }^{27,28}$ The morphological analysis of these systems demonstrated that the spray-dried powders presented spherical microparticles showing nanoparticles on their surfaces.

Recently we have associated melatonin into nanoparticles systems, prepared by the nanoprecipitation technique. These nanoparticles provided an important increase in the effect of melatonin against lipid peroxidation of the microsomes and phosphatidylcoline liposomes. ${ }^{29}$ Taking these results into account, the aim of the present work is to prepare and to characterize nanocapsule suspensions containing melatonin, studying the influence of the formulation composition on the physico-chemical properties of these colloids. For comparison, nanospheres and nanoemulsion were also prepared. The formulations were characterized in terms of the macroscopic and microscopic aspects, the particle mean diameters, the $\mathrm{pH}$ values, the melatonin contents and the encapsulation efficiencies. The possibility of preparing melatonin-loaded nanocapsule spray-dried powders with the aim of improving the stability of these aqueous systems and controlling the release of this drug has been also investigated.

\section{Experimental}

\section{Chemicals and reagents}

Melatonin was obtained from Sigma (St. Louis, USA). Poly(E-caprolactone) $\left[\mathrm{MW}=60,000 \mathrm{~g} \mathrm{~mol}^{-1}\right]$ and poly(lactide) (Resomer ${ }^{\circledR}$ R 206) were supplied by Aldrich (Strasbourg, France) and Boehringer Ingelheim (Germany), respectively. Eudragit S $100^{\circledR}$ and Eudragit RS $100^{\circledR}$ were obtained from Almapal (São Paulo, Brazil). Caprylic/capric triglyceride and mineral oil were obtained from Brasquim (Porto Alegre, Brazil) and Fraccionata (Porto Alegre, Brazil), respectively. Sorbitan monostearate $\left(\operatorname{Span} 60^{\circledR}\right)$, sorbitan monooleate $\left(\operatorname{Span} 80^{\circledR}\right.$ ) and polysorbate 80 (Tween $80^{\circledR}$ ) were acquired from Delaware (Porto Alegre, Brazil). Poloxamer 188 (Pluronic ${ }^{\circledR}$ F68) was obtained from Sigma (St. Louis, USA). All other chemicals and solvents used were of pharmaceutical grade. All reagents were used as received.

Preparation of nanocapsule suspensions by interfacial deposition of a preformed polymer

Nanocapsules containing melatonin were prepared as described by Fessi et al..$^{30}$ Briefly, the lipophilic solution consisted of $0.8 \mathrm{~mL}$ oil (caprylic/capric triglyceride or mineral oil), $250 \mathrm{mg}$ polymer [poly( $\varepsilon$ caprolactone), poly(lactide), Eudragit ${ }^{\circledR}$ S100 or Eudragit ${ }^{\circledR}$ 
RS100)], melatonin (0.5 mg mL $\left.\mathrm{m}^{-1}\right), 192 \mathrm{mg}$ surfactant (Span $60^{\circledR}$ or Span $80^{\circledR}$ ) and $67 \mathrm{~mL}$ acetone. This organic phase was added with magnetic stirring into an aqueous solution (133 mL) containing $192 \mathrm{mg}$ surfactant (Tween $80^{\circledast}$ or Pluronic $\left.\mathrm{F} 68^{\circledR}\right)$. The solvents were removed by evaporation under reduced pressure and the final volume of suspension was adjusted to a total volume of $25 \mathrm{~mL}$. Nanospheres and nanoemulsion were also prepared as described above for nanocapsules, omitting the oil and the polymer, respectively.

\section{Characterization of suspensions}

The physicochemical analysis of nanoparticles was carried out immediately after preparation. The $\mathrm{pH}$ values of suspensions were determined using potentiometer B474 (Micronal, Brazil) after preparation. The particle size was mensured by photon correlation spectroscopy (PCS). For PCS measurements, $20 \mu \mathrm{L}$ of each suspension were diluted to $10 \mathrm{~mL}$. Measurements were made at room temperature $\left(20^{\circ} \mathrm{C}\right)$ and fixed angle of $90^{\circ}$, using a Brookheaven Instruments standard setup (BI-200M goniometer, BI9000AT digital correlator and a BI9863 detection system). A Spectra Physics He-Ne laser (model 127, $\lambda_{0}=632,8$ $\mathrm{nm}$ ) was used as light source. ${ }^{28}$ The morphological analysis was conducted by transmission electron microscopy (TEM; Jeol, JEM 1200 Exll) operating at $80 \mathrm{kV}$. For this analysis, the diluted suspension was deposited in FormvarCarbon support film on specimen grid (Electron Microscopy Sciences) and negatively stained with uranyl acetate solution $(2 \% \mathrm{~m} / \mathrm{v})$.

\section{Determination of drug content for nanoparticle suspensions}

Melatonin was assayed by high-performance liquid chromatography. ${ }^{29}$ The system consisted of a UV/visible detector, pump and auto-injector S 200 Perkin Elmer (Shelton, USA) and Nova-Pak ${ }^{\circledR} \mathrm{C}_{18} 3.9$ x $300 \mathrm{~mm}$ Waters column. The mobile phase consisted of acetonitrile/water (55:45). The total sample volume injected was $20 \mu \mathrm{L}$ and melatonin was detected at $229 \mathrm{~nm}$. Free melatonin (nonassociated) was determined in the ultrafiltrate after separation of the nanoparticles by ultrafiltrationcentrifugation technique (Ultrafree-MC 10,000 MW, Millipore), at 15,300 x g for $10 \mathrm{~min}$. Total melatonin was measured using HPLC after the dissolution of colloidal suspension by acetonitrile. The melatonin associated with the nanoparticles (encapsulation efficiency) was calculated from the difference between the total and free drug concentrations measured in the nanoparticles suspension and in the ultrafiltrate, respectively.
Preparation of nanocapsule spray-dried powders

To the suspension of nanocapsules was added $3 \%(\mathrm{~m} / \mathrm{v})$ of colloidal silicon dioxide and the mixture was fed into a mini-spray-dryer Büchi MSD 190 (Flawil, Switzerland) with a two-component nozzle and co-current flow. ${ }^{27}$ The inlet temperature at the drying chamber was maintained around $150{ }^{\circ} \mathrm{C} \pm 4{ }^{\circ} \mathrm{C}$ and outlet temperature was $107 \pm 4{ }^{\circ} \mathrm{C}$. The spray rate feed was $3 \mathrm{~mL} \mathrm{~min}{ }^{-1}$. The spray-dried powders were prepared in triplicate.

\section{Characterization of nanocapsule spray-dried powder}

The yields of the spray-dried powders were calculated by the sum of the weights of all components, discounting the content of water in the suspensions. After stirring the powders in acetonitrile for 90 minutes, at room temperature, followed by centrifugation and filtration (membrane GVWP, $0.45 \mu \mathrm{m}$, Millipore) the encapsulation efficiency of melatonin was determined by HPLC (Waters, USA - pump 600 controller; 2487 Dual $\lambda$ absorbance detector; 717 plus autosampler). The Merck column LiChrospher ${ }^{\circledR}$ RP-18 (250 x $4 \mathrm{~mm}$; Germany) was employed. The mobile phase consisted of acetonitrile/water (55:45). The total sample volume injected was $20 \mu \mathrm{L}$ and melatonin was detected at $229 \mathrm{~nm}$. The encapsulation efficiency (\%) of spray-dried powder was calculated from the correlation of the theoretical and the experimental melatonin concentrations. The spraydried powders, after gold sputtering, were examined under scanning electron microscopy (SEM) (Jeol Scanning Microscope, JSM-5800) at $20 \mathrm{kV}$, using different magnifications, according to the methodology previously described in the literature. ${ }^{16,27}$ The moisture (\%) was determined using Karl Fischer titration (Schott Titroline Alpha). The particle size distribution was determined by laser diffractometry using a Malvern laser sizer (Mastersizer 2000). Average particle size was expressed as volume mean diameter $\left(\mathrm{d}_{4,3}\right)$ in $\mu \mathrm{m}$. The span was also calculated and it is defined as $\left(\mathrm{d}_{(\mathrm{v}, 90)}-\mathrm{d}_{(\mathrm{v}, 10)}\right) / \mathrm{d}_{(\mathrm{v}, 50)}$, where $\mathrm{d}_{(\mathrm{v}, 90)}, \mathrm{d}_{(\mathrm{v}, 10)}$ and $\mathrm{d}_{(\mathrm{v}, 50)}$ are the diameters at $90 \%, 10 \%$ and $50 \%$ cumulative volume, respectively. Thus, the span gives a measure of the range of the volume distribution relative to the median diameter.

\section{In vitro drug release studies from spray-dried powders}

The in vitro melatonin release test of the nanocapsule spray-dried powders was carried out using a flow-through cell technique. The apparatus is constituted by recycling flow-through cells (Desaga, Wiesloch, Germany) containing as a fluid inlet a bed of glass beads, and connected to a peristaltic pump (Desaga, Wiesloch, 
Germany). The flow rate was $1 \mathrm{~mL} \min ^{-1}$. The test was carried out using $\mathrm{pH} 7.4$ phosphate buffer solution. The dissolution medium $\left(37 \pm 0.5^{\circ} \mathrm{C}\right)$ was placed in an external vessel, connected with the cell through the pump. An exact amount of each powder (equivalent to $2 \mathrm{mg}$ of melatonin) was placed in the cells for the release tests $(n=3)$. The collected samples, at predetermined time intervals, were filtered through a membrane (GVWP, $0.45 \mu \mathrm{m}$, Millipore). The drug release/dissolved was assessed through HPLC analysis, as described above. The dissolution profiles of the drug were analyzed by mathematical models using the MicroMath Scientist ${ }^{\circledast}$ Program.

\section{Physical stability evaluation of formulations}

The nanocapsule suspension prepared using Eudragit ${ }^{\circledR}$ S100 and its corresponding spray-dried powders were stored, at room temperature and protected from light, for 12 months. The physical aspect of these formulations was evaluated after preparation and after 12 months of storage.

\section{Results and Discussion}

\section{Influence of the formulation composition on the physico- chemical characteristics of melatonin loaded-nanocapsule suspensions}

The parameters of the formulations studied were the oil nature, the type of surfactant and the type of polymer. The melatonin-loaded polymeric nanocapsules were obtained by interfacial deposition of preformed polymers using different components. All formulations presented macroscopic homogeneous aspect like a milky white bluish opalescent fluid (Tyndall effect) in agreement with the results previously reported in the literature for other nanocapsule systems. . $^{15,24,31}$

Tables 1 and 2 show the physico-chemical characteristics of nanocapsule suspensions containing melatonin. These systems presented colloidal sizes between 204 and $280 \mathrm{~nm}$, corroborating results previously observed for nanocapsules prepared by interfacial deposition. ${ }^{15,24,26,31}$ The suspensions showed acid $\mathrm{pH}$ values (3.97-5.62) and the total concentrations of melatonin were recovered as expected $\left(0.5 \mathrm{mg} \mathrm{mL}^{-1}\right)$.
Regarding the melatonin-encapsulation efficiencies, the values ranged between 33 and 56\%, depending on the composition of the formulations (Table 1 and 2). Concerning the influence of oil core, the melatoninencapsulation efficiency for the caprylic/capric triglyceride $(37 \%)$ was slightly higher than that for the mineral oil $(31 \%)$. Moreover, the oil nature did not influence the size of the poly( $\varepsilon$-caprolactone)-nanocapsules containing melatonin (caprylic/capric triglyceride $=264 \pm 24 \mathrm{~nm}$; mineral oil $=266 \pm 40 \mathrm{~nm}$ ).

Nanocapsules can be stabilized by steric or electrostatic repulsion, depending on the nature of the surfactant. Surfactants are necessary to obtain small and stable oil droplets. ${ }^{32}$ In this way, surfactants can affect the physico-chemical properties of the nanoparticles, such as size and drug loading. ${ }^{32,33}$ However, in this work, the nature of surfactants (Table 1) did not present a major influence on the size of particles and on the drug encapsulation for poly( $\varepsilon$-caprolactone)-nanocapsules containing melatonin.

The melatonin-encapsulation efficiency was mainly influenced by the polymer nature (Table 2). The formulations prepared with polymethacrylates (Eudragit ${ }^{\circledR}$ RS100 and Eudragit ${ }^{\circledast}$ S100) presented the encapsulation efficiencies of $45 \%$ and $56 \%$ (Table 2), respectively, while using polyesters [poly( $\varepsilon$-caprolactone) and poly(lactide acid)] these values were around $37 \%$. These results could be attributed to the difference of the drug affinity for the polymeric materials.

It was verified that melatonin-encapsulation efficiencies into Eudragit ${ }^{\circledR}$ S100-nanocapsules $(56 \%)$ are higher than for nanoemulsion formulations (33\%) that have been prepared in the absence of the polymer (Table 3 ).

Table 2. The influence of the type of the polymer on physicochemical characteristics of nanocapsule suspensions containing melatonin $(0.5 \mathrm{mg}$ $\mathrm{mL}^{-1}$ ), prepared using polysorbate 80 , sorbitan monooleate, and caprylic/ capric triglyceride as oil core

\begin{tabular}{lcccc}
\hline Polymer & $\begin{array}{c}\text { Total Conc. } \\
\left(\mathrm{mg} \mathrm{mL}^{-1}\right)\end{array}$ & $\begin{array}{c}\text { Melatonin } \\
\text { Encapsulated } \\
(\%)\end{array}$ & $\begin{array}{c}\text { Size } \\
(\mathrm{nm})\end{array}$ & $\mathrm{pH}$ \\
\hline Poly(c-caprolactone) & 0.49 & 37 & $264 \pm 24$ & 5.38 \\
Poly(lactide) & 0.48 & 38 & $216 \pm 36$ & 4.08 \\
Eudragit RS100 $^{\circledR}$ & 0.51 & 45 & $204 \pm 30$ & 4.29 \\
Eudragit S100 $^{\circledR}$ & 0.52 & 56 & $236 \pm 20$ & 3.97 \\
\hline
\end{tabular}

Table 1. The influence of the type of the surfactant on physicochemical characteristics of poly( $\varepsilon$-caprolactone)-nanocapsule suspensions containing melatonin $\left(0.5 \mathrm{mg} \mathrm{mL}^{-1}\right)$, using caprylic/capric triglyceride as oil core

\begin{tabular}{lcccc}
\hline Surfactants & Total Conc. $\left(\mathrm{mg} \mathrm{mL}^{-1}\right)$ & Melatonin Encapsulated (\%) & Size (nm) & $\mathrm{pH}$ \\
\hline Sorbitan monooleate/ Pluronic F68 & 0.50 & 33 & $280 \pm 14$ & 5.62 \\
Sorbitan monostearate/ polysorbate 80 & 0.45 & 36 & $264 \pm 48$ & 4.37 \\
Sorbitan monooleate/ polysorbate 80 & 0.49 & 37 & $264 \pm 24$ & 5.38 \\
\hline
\end{tabular}


In the case of poly( $\varepsilon$-caprolactone), no significant increase in drug entrapment has been verified comparing the systems prepared with the polymer (37\%) or in its absence (33\%). Comparing the size of the nanocapsules (204-264 nm; Table 2) and nanoemulsion ( $246 \mathrm{~nm}$; Table 3), it can be observed that the presence of polymers in the former did not influence the diameter of the particles. Similar results were observed for poly ( $\varepsilon$-caprolactone)-nanocapsules $(236 \mathrm{~nm})$ and nanoemulsion $(216 \mathrm{~nm})$ containing indomethacin, prepared using Miglyol ${ }^{\circledR} 840 .{ }^{34}$

The formulations prepared with poly( $\varepsilon$-caprolactone) or Eudragit ${ }^{\circledR}$ S100 (nanospheres and nanocapsules) presented similar encapsulation efficiencies (Table 3). On the other hand, the absence of an oil core in nanospheres led to smaller particles (126 and $182 \mathrm{~nm}$ ) compared to the nanocapsules (236 and $264 \mathrm{~nm}$ ). These differences of size between nanocapsules and nanospheres have also been reported for other similar systems..$^{26,35}$

According to Figure 2, the TEM micrographs of melatonin-loaded Eudragit ${ }^{\circledR}$ S100-nanocapsules present spherical shape as well as homogeneous size distribution. Observing these images, the particles show size around 200 $\mathrm{nm}$ confirming the results obtained by PCS (Table 2).

\section{Nanocapsule spray-dried powders}

Based on the highest melatonin-encapsulation efficiency, the nanocapsules prepared with Eudragit ${ }^{\circledR}$ S100 (Table 2) were selected to be spray-dried in order to obtain nanocapsule spray-dried powder containing melatonin. In this way, the process yields were $74 \pm 2 \%$, similar to those described in our previous works for non-steroidal antiinflammatory drugs spray-dried powders using silicon dioxide as drying adjuvant. ${ }^{27}$ The encapsulation efficiency of melatonin in these powders was $93 \pm 3 \%$, and moisture content was lower than $2 \%$.

Concerning the morphological analysis of spray-dried powders performed by SEM (Figures 3a, 3c, 3e), the microparticles presented spherical shape and relatively narrow diameter distribution. The microparticles presented $\mathrm{d}_{(4,3)}$ of $5.8 \mu \mathrm{m}$ and $\mathrm{d}_{(\mathrm{v}, 90)}, \mathrm{d}_{(\mathrm{v}, 50)}$ and $\mathrm{d}_{(\mathrm{v}, 10)}$ were $10.3 \mu \mathrm{m}$, $4.9 \mu \mathrm{m}$ and $2.4 \mu \mathrm{m}$, respectively. The relatively narrow
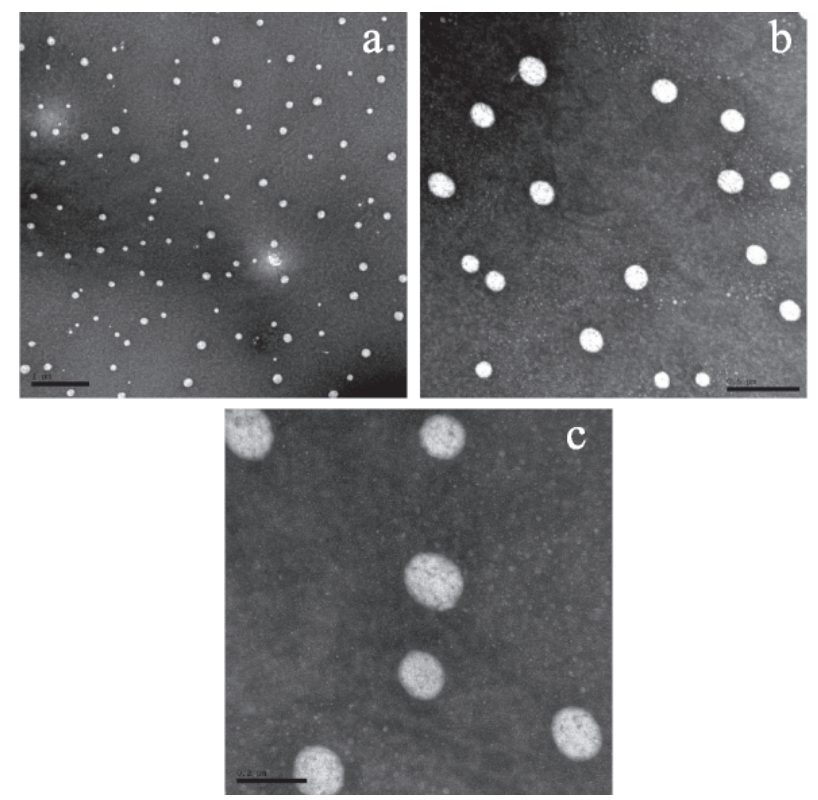

Figure 2. Transmission electron microscopy images of Eudragit $\mathrm{S} 100^{\circledR}$ nanocapsule suspension containing melatonin $[\mathrm{bar}=1 \mu \mathrm{m}(\mathrm{a}), 0.5 \mu \mathrm{m}$ (b), $0.2 \mu \mathrm{m}$ (c)].

diameter distribution observed by SEM analysis was confirmed by the low span value (1.6) $)^{36}$ and it was in accordance with the range obtained for other microparticle systems prepared by spray-drying technique. ${ }^{37}$

Through SEM analysis, at higher magnification (Figures $3 \mathrm{~b}, 3 \mathrm{~d}$ ), nanostructures were observed on the surfaces of the microparticles. These results can be confirmed comparing these Eudragit ${ }^{\circledast}$ S100-nanocapsule spray-dried surfaces (Figures 3b, 3d) with particle surfaces of raw silicon dioxide spray-dried (Figure $3 \mathrm{f}$ ) powder. The nanostructures observed presented size about $200 \mathrm{~nm}$ (Figures 3b, 3d) similar to those observed for the corresponding original suspension by PCS (Table 2 and Figure 2).

\section{Physical stability evaluation}

Regarding the stability, after 3.5 months of preparation at room temperature, the Eudragit ${ }^{\circledR}$ S100-nanocapsule suspension presented precipitates on the wall of flasks, demonstrating its physical instability as a function of the storage time. After 12 months, this suspension presented two

Table 3. Influence of the presence of polymer and/or oil, on physicochemical characteristics of several colloidal formulations containing melatonin ( 0.5 $\mathrm{mg} \mathrm{mL}^{-1}$ ), prepared using polysorbate 80 and sorbitan monooleate as surfactants

\begin{tabular}{|c|c|c|c|c|c|c|}
\hline Polymer & System & Oily core & Total Conc. (mg mL $\mathrm{mL}^{-1}$ ) & Melatonin encapsulated (\%) & Size $(\mathrm{nm})$ & $\mathrm{pH}$ \\
\hline Eudragit S100 ${ }^{\circledR}$ & Nanospheres & - & 0.46 & 54 & $126 \pm 12$ & 3.88 \\
\hline Eudragit S100 ${ }^{\circledR}$ & Nanocapsules & Triglyceride $^{a}$ & 0.52 & 56 & $236 \pm 20$ & 3.97 \\
\hline Poly(E-caprolactone) & Nanospheres & - & 0.48 & 39 & $182 \pm 8$ & 5.04 \\
\hline Poly( $\varepsilon$-caprolactone) & Nanocapsules & Triglyceride $^{a}$ & 0.49 & 37 & $264 \pm 24$ & 5.38 \\
\hline- & Nanoemulsion & Triglyceride $^{a}$ & 0.49 & 33 & $246 \pm 4$ & 5.15 \\
\hline
\end{tabular}

${ }^{\mathrm{a}}$ Caprylic/capric triglyceride. 

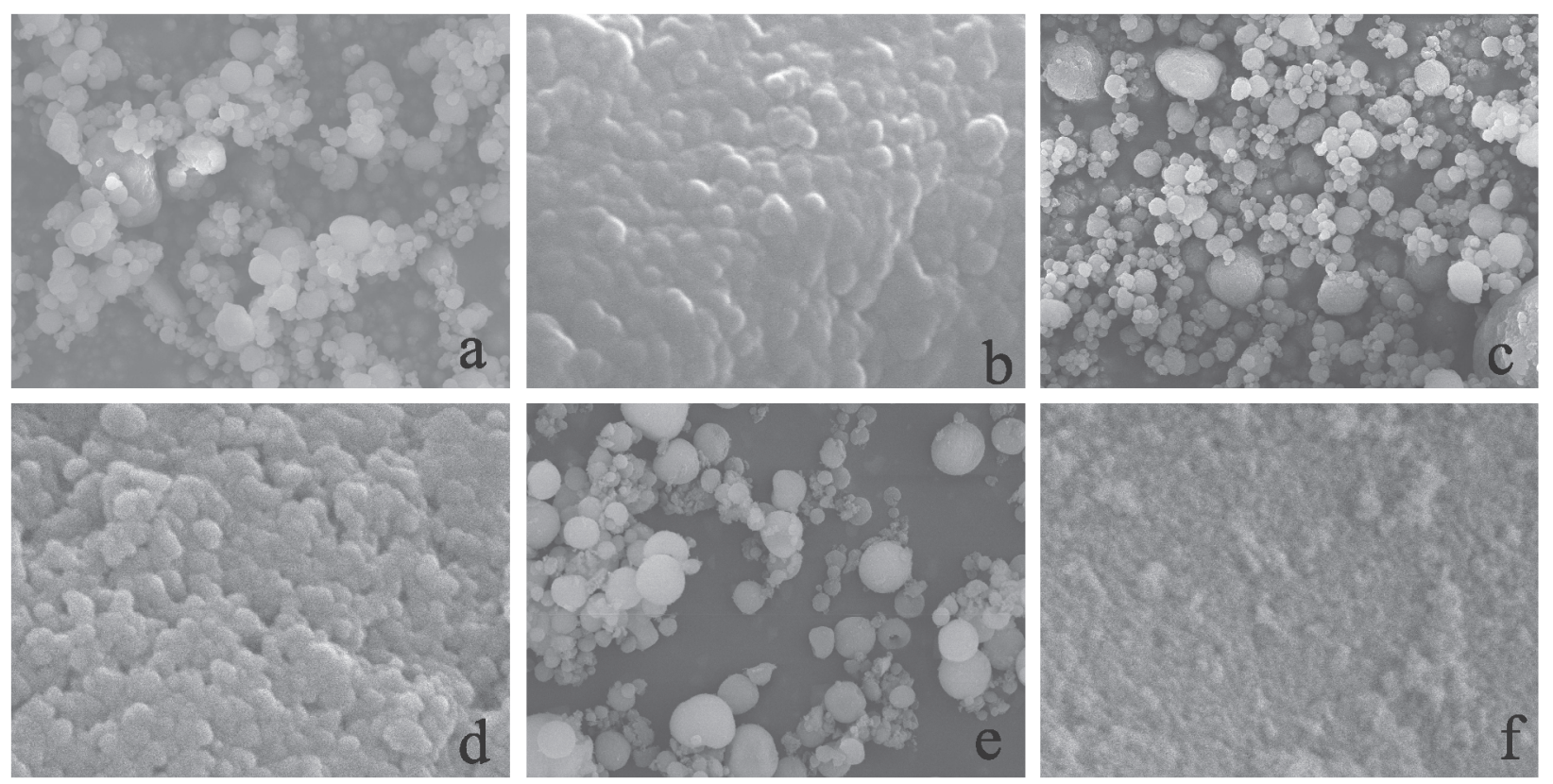

Figure 3. Images obtained by scanning electron microscopy (SEM) of the Eudragit $\mathrm{S} 100^{\circledR}$ nanocapsule spray-dried powder containing melatonin, after preparation (a,b) and after 12 months of storage (c,d) and silicon dioxide spray-dried (e, f). [a, c, e (1,000 X) - the photo width corresponds to $132 \mu \mathrm{m}]$; [b, $\mathrm{d}, \mathrm{f}(45,000 \mathrm{X})$ - the photo width corresponds to $2.93 \mu \mathrm{m}]$.

particle populations, one presenting mean diameter of $283 \pm$ $55 \mathrm{~nm}$ and the other presenting size larger than $1000 \mathrm{~nm}$, showing particle agglomeration (initial diameter is $236 \pm$ $20 \mathrm{~nm}$, Table 2). On the other hand, this spray-dried nanocapsule formulation presented stable macroscopic aspect after 12 months of storage. In addition, comparing the initial microscopic aspect of the powders (Figures $3 a$ and $3 b$ ) with that observed after 12 months of storage (Figures $3 \mathrm{c}$ and 3d), no morphological alterations were verified.

\section{In vitro release profiles}

Figure 4 shows the release profile of melatonin from the Eudragit ${ }^{\circledast}$ S100-nanocapsule spray-dried powder and the dissolution of the pure drug. Mathematical modeling (zero order, first order, biexponential) was applied to obtain information about the kinetics of melatonin dissolution and release behavior. After fitting these models, the model was selected based on the highest correlation coefficient (r) and highest model selection criterion (MSC), as well as the best curve fitting. MSC is a modified Akaike information criterion provided by the MicroMath Scientist ${ }^{\circledR}$ Program that allows the comparison of various data sets fitted to a selected model. Greater MSC values indicate more appropriate fits. According to these criteria, both zero order and biexponential models failed to fit the dissolution and release profiles. The monoexponential (first order) was the best model to describe the dissolution and release profiles for both pure and encapsulated drug (Figure 4). In this way, it was observed that the release rate of melatonin-loaded nanocapsule spraydried powder has been modified in comparison with the dissolution profile of the pure melatonin in $\mathrm{pH} 7.4$ phosphate buffer solution. In this medium, after two hours $96 \%$ and $71 \%$ of melatonin were dissolved from pure drug and released from nanocapsule spray-dried powder, respectively. For the pure melatonin, the dissolution rate constant $(k)$ was $0.023 \pm$ $0.003 \mathrm{~min}^{-1}$, while for melatonin-loaded spray-dried powder it was $0.010 \pm 0.001 \mathrm{~min}^{-1}$, showing a slower melatonin dissolution from the powder than from the pure drug.

In order to gain some insight into the drug release mechanism, a very simple and semi-empirical equation to describe drug release from polymeric systems, the power law (Krosmeyer-Peppas model), was also applied $\left(\mathrm{f}_{t}=\mathrm{a} \cdot \mathrm{t}^{\mathrm{n}}\right)$. In this equation, $f_{t}$ is the drug dissolved fraction at time $t, n$ is the release exponent, indicative of the mechanism of the drug release and $a$ is the constant incorporating structural and geometric characteristics of the drug dosage form. ${ }^{38}$ For spherical systems, when the exponent $n$ assumes a value of 0.43 , between 0.43 and $0.85,0.85$ or greater than 0.85 the drug release rate is governed by fickian diffusion, anomalous transport, Case-II transport, or super Case-II transport, respectively. The parameters $a$ and $n$ were obtained from the initial portion of the curve $(\%$ released $\leq$ $60 \%$; Figure 5), according to the literature. ${ }^{39,40}$ In this work, the power law presents the corresponding fit: $\mathrm{f}_{\mathrm{t}}=1.001$ $\mathrm{t}^{0.908}, \mathrm{r}=0.998$ (MSC $=5.09$ ). This calculated exponent $n$ shows that melatonin release mechanism is based on super Case-II transport (non-Fickian model). In this way, the 


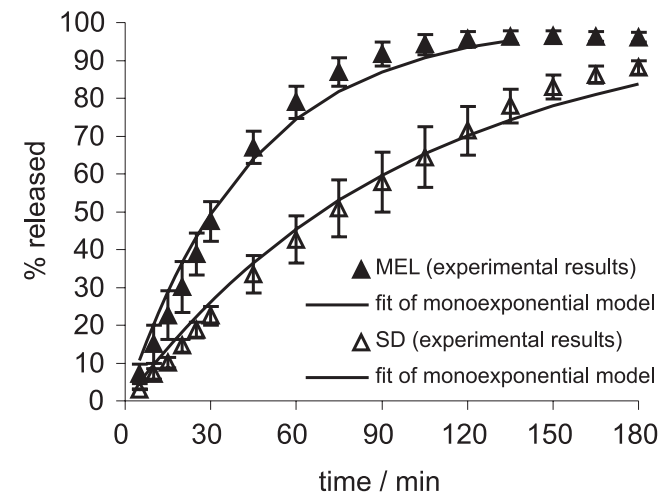

Figure 4. The release profile of melatonin-loaded nanocapsule spraydried powder (SD) in comparison with the dissolution of the pure drug (MEL), in $\mathrm{pH} 7.4$ fosphate buffer solution.

melatonin release can be explained by the superposition of swelling, relaxation and dissolution of the polymer, which dissolves in $\mathrm{pH}$ values above 7.0. ${ }^{41}$

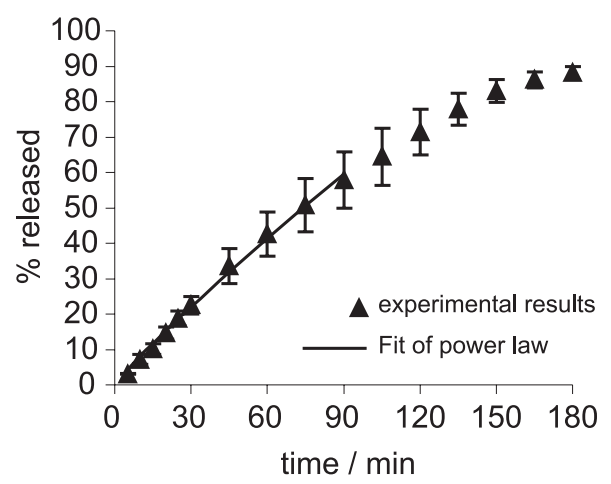

Figure 5. Fit of experimental melatonin release from Eudragit ${ }^{\circledR}$ S100nanocapsule spray-dried powder by Krosmeyer-Peppas model (drug release limited up to $60 \%$ ).

\section{Conclusions}

Results from this investigation showed that homogeneous nanocapsule suspensions containing melatonin can be prepared using preformed polymers by interfacial deposition technique. The physico-chemical characteristics of these systems have been altered depending on the composition of the formulations. In addition, the melatonin loadednanocapsule spray-dried powder prepared using silicon dioxide has been successfully obtained. This powder improved the physical stability of the product compared to the original nanocapsule aqueous suspension. The melatoninloaded nanocapsule spray-dried powder showed a controlled release profile in comparison to the dissolution of the pure melatonin. The monoexponential model was the best one to describe the dissolution and release profiles. Moreover, regarding the parameters calculated using the power law, it was suggested that the melatonin release from Eudragit ${ }^{\circledR}$ S100-nanocapsule spray-dried powder was governed by swelling, relaxation and dissolution of the polymer.

\section{Acknowledgments}

We thank financial support received from $\mathrm{CNPq}$, FAPERGS, CAPES, Rede Nanobiotec-CNPq/MCT-Brazil.

\section{References}

1. Beyer, C. E.; Steketee, J. D.; Saphier, D.; Biochem. Pharmacol. 1998, 56, 1265; Reiter, R. J.; Best Pract. Res. Clin. Endoc. Metab. 2003, 17, 273; Cajochen, C.; Kräuchi, K.; Wirz-Justice, A.; J. Neuroendocrinol. 2003, 15, 432.

2. Liebmann, P.; Wöler, A.; Felsner, P.; Hofer, D.; Schauenstein, K.; Int. Arch. Allergy Immunol. 1997, 112, 203.

3. Brömme, H. J.; Mörke, W.; Peschke, E.; Ebelt, H.; Peschke, D.; J. Pineal Res. 2000, 29, 201.

4. Leaden, P.; Barrionuevo, J.; Catalá, A.; J. Pineal Res. 2002, 32, 129; Saija, A.; Tomaino, A.; Trombetta, D.; Pellegrino, M. L.; Tita, B.; Caruso, S.; Castelli, F.; Eur. J. Pharm. Biopharm. 2002, 53, 209; Teixeira, A.; Morfim, M. P.; Cordova, C. A. S.; Charão, C. C. T.; Lima, V. R.; Creczynski-Pasa, T. B.; J. Pineal Res. 2003, 35, 262.

5. Pappolla, M. A.; Simovich, M. J.; Bryant-Thomas, T.; Chyan, Y-J.; Poeggler, B.; Dubobovich, M.; Bick, R.; Perry, G.; CruzSamchez, F.; Simith, M. A.; J. Pineal Res. 2002, 32, 135.

6. Reiter, R. J.; Tan, D-X.; Cardiovasc. Res. 2003, 58, 10.

7. Vijayalaxmi, C. R. T.; Reiter, R. J.; Herman, T. S.; J. Clin. Oncol. 2002, 20, 2575.

8. Lee, B-J.; Ryu, S-G.; Cui, J-H.; Drug Dev. Ind. Pharm. 1999, $25,493$.

9. El-Gibaly, I.; Meki, A. M. A.; Abdel-Ghaffar, S. K.; Int. J. Pharm. 2003, 260, 5.

10. Lee, B-J.; Parrot, K. A.; Ayres, J. W.; Sack, R. L.; Int. J.Pharm. 1995, 124, 119.

11. Lee, B-J.; Mim, G-H.; Int. J. Pharm. 1996, 144, 37.

12. Lee, B-J.; Parrot, K. A.; Ayres, J. W.; Sack, R. L.; Drug Dev. Ind. Pharm. 1996, 22, 269.

13. Lee, B-J.; Choe, J. S.; Kim, C-K.; J. Microencapsul. 1998. 15, 775.

14. El-Gibaly, I.; Int. J. Pharm. 2002, 249, 7.

15. Couvreur, P.; Barrat, G.; Fattal, E.; Legrand, P.; Vauthier, C.; Crit. Rev. Ther. Drug Carr. Syst. 2002, 19, 99.

16. Schaffazick, S. R.; Guterres, S. S.; Lucca-Freitas, L.; Pohlmann, A. R.; Quim. Nova 2003, 26, 726.

17. Legrand, P.; Barratt, G.; Mosqueira, V.; Fessi, H.; Devissaguet, J-P.; S. T. P. Pharma Sci. 1999, 9, 411.

18. Vauthler-Holtzcherer, C.; Benabbou, S.; Spenlehauer, G.; Veillard, M.; Couvreur, P.; STP Pharma Sci. 1991, 1, 109; Quintanar-Guerrero, D.; Allémann, E.; Fessi, H.; Doelker, E.; Drug Dev. Ind. Pharm. 1998, 24, 1113.

19. Couvreur, P.; Dubernet, C.; Puisieux, F.; Eur. J. Pharm. Biopharm. 1995, 41, 2. 
20. Guterres, S. S.; Müller, C. R.; Michalowski, C. B.; Pohlmann, A. R.; Dalla-Costa, T.; STP Pharma Sci. 2001, 11, 229.

21. Verger, M.L-Le.; Fluckiger, L.; Kim, Y-II.; Hoffman, M.; Maincent, P.; Eur. J. Pharm. Biopharm. 1998, 46, 137.

22. Allémann, E; Leroux, J-C.; Gurny, R.; Adv. Drug Deliv. Rev. 1998, 34, 171 .

23. Saez, M.; Gusmán, M.; Molpeceres, J.; Aberturas, M. R.; Eur. J. Pharm. Biopharm. 2000, 50, 379;

24. Schaffazick, S. R.; Pohlmann, A. R.; Lucca-Freitas, L.; Guterres, S. S.; Acta Farm. Bonaerense 2002, 21, 99.

25. Molpeceres, J.; Aberturas, M.R.; Chacón, M.; Berges, L.; Guzmán, M.; J. Microencapsul. 1997, 14, 777.

26. Schaffazick, S. R.; Pohlmann, A. R.; Dalla-Costa, T.; Guterres, S. S.; Eur. J. Pharm. Biopharm. 2003, 56, 501.

27. Müller, C. R.; Bassani, V. L.; Pohlmann A. R.; Michalowski, C. B.; Petrovick, P. R.; Guterres, S. S.; Drug Dev. Ind. Pharm. 2000, 26, 343; Guterres, S. S; Weiss, V.; Lucca-Freitas, L.; Pohlmannm, A. R.; Drug Deliv. 2000, 7, 195; Müller, C. R.; Schaffazick, S. R.; Pohlmann, A. R.; Lucca-Freitas, L.; Silveira, P.; Dalla-Costa, T.; Guterres, S. S.; Pharmazie 2001, 56, 864; Beck, R. C. R.; Pohlmann, A. R.; Benvenutti, E. V.; Costa, T. D.; Guterres, S. S.; J. Braz. Chem. Soc. 2005, 16, 1233.

28. Pohlmann, A. R.; Weiss, V.; Mertins, O.; Pesce da Silveira, N.; Guterres, S. S.; Eur. J. Pharm. Sci. 2002, 16, 305.

29. Schaffazick, S. R.; Pohlmann, A.R.; de Cordova, C. A. S.; Creczynski-Pasa, T. B.; Guterres, S. S.; Int. J. Pharm. 2005, 289, 209.

30. Fessi, H.; Puisieux, F.; Devissaguet, J-Ph; Ammoury, N.; Benita, S.; Int J. Pharm. 1989, 55, r1.
31. Santos-Magalhães, N. S.; Pontes, A.; Pereira, V. M. W.; Caetano, M. N. P.; Int. J. Pharm. 2000, 208, 71.

32. Mosqueira, V. C. F.; Legrand, P.; Pinto-Alphandary, H.; Puisieux, F.; Barratt, G.; J. Pharm. Sci. 2000, 89, 614.

33. Magenheim, B.; Benita, S.; S. T. P. Pharma Sci. 1991, 1, 221; Paul, M.; Fessi, H.; Laatiris, A.; Boulard, Y.; Durand, R.; Deniau, M.; Astier, A.; Int. J. Pharm. 1997, 159, 223.

34. Calvo, P.; Vila-Jato, J. L.; Alonso, M. J.; J. Pharm. Sci. 1996, $85,530$.

35. Teixeira, M.; Alonso, M. J.; Pinto, M. M. M.; Barbosa, C. M.; Eur. J. Pharm. Biopharm. 2005, 59, 491.

36. Chen, J.; Davis, S. S.; J. Microencapsul. 2002, 19, 191.

37. Oneda, F.; Ré, M. I.; Powder Technol. 2003, 130, 377.; Oliveira, B. F.; Santana, M. H. A.; Ré, M. I.; Braz. J. Chem. Eng. 2005, 22, 353.

38. Krosmeyer, R. W.; Gurny, R.; Doelker, E. M.; Buri, P.; Peppas, N. A.; Int. J. Pharm. 1983, 15, 25.

39. Costa, P.; Lobo, J. M. S.; Eur. J. Pharm. Sci. 2001, 13, 123; Siepmann, J.; Peppas, N.A.; Adv. Drug Deliv. Rev. 2001, 48, 139.

40. Sezer, A. D.; Akbuga, J.; Int. J. Pharm. 1995, 121, 113; Bonferoni, M. C.; Rossi, S.; Ferrari, F.; Bertoni, M.; Bolhuis, G. K.; Caramella, C.; J. Control. Release 1998, 51, 231.

41. Kibbe, A.H.; Handbook of Pharmaceutical Excipients, $3^{\text {th }}$ ed., American Pharmaceutical Association: Washington, 2000.

Received: August 14, 2005 Published on the web: April 12, 2006 